\title{
USE OF PHYSICAL AND CHEMICAL RESPONSE IN CAVE DRIPS TO CHARACTERIZE UPLAND RECHARGE IN THE BARTON SPRINGS SEGMENT OF THE EDWARDS AQUIFER, CENTRAL TEXAS, USA
}

\author{
Brian Cowan \\ Zara Environmental LLC, 1707 FM1626, Manchaca, Texas, 78652, brian@zaraenvironmental.com
}

Nico Hauwert

City of Austin Watershed Protection Department, PO Box 1088, Austin, Texas, 78767,nico.hauwert@austintexas.gov

\begin{abstract}
Cave drips are useful for characterizing recharge and transport through soils, particularly in upland karst settings. Estimation of upland recharge is important for the Barton Springs Segment (BSS) of the Edwards Aquifer, but discrepancies between previous and recent studies indicate how little is known about it in the BSS. We outline a methodology for using cave drips to characterize upland recharge and present initial findings from a study of drips in four BSS caves.

Soils in the BSS are heterogeneous, making it difficult to characterize their hydraulic properties over larger areas, particularly with methods that only yield information about a discrete location (i.e., infiltration tests, moisture sensors). This is particularly true in the BSS where thin, clay-rich, soils often contain macropores (i.e., desiccation cracks, roots, burrows) that act as preferential flowpaths for rapid recharge through the soil zone. Cave drips are well suited for characterizing recharge in upland areas as they often have large source areas.
\end{abstract}

Drip responses to storm events were monitored at drips in three BSS caves. Hydrograph separation and chemical analyses allowed distinction of fast flow, through macropores and conduits, from slow flow drainage primarily from the soil column. Natural and artificial soil tracers indicate that surface water reaches many of the drips within a few hours of the onset of storm events, even though reported soil Ksat values of $0.06-0.57 \mathrm{in} / \mathrm{hr}$ are relatively low, and no discrete recharge was observed within the subsurface drainage basin of three of the caves. These results indicate that upland recharge may contribute a greater portion of total recharge in the BSS than previously estimated, and that rapid recharge can occur in the absence or discrete recharge features likely via macropore flow.

\section{Introduction}

Karst aquifers develop in soluble rock where groundwater flows through and enlarges voids by dissolution. They are well known for the development of efficient internal drainage basins that rapidly recharge water beyond the depth of transpiration and evaporation (Jennings, 1985). Diffuse infiltration entering an aquifer through soil and fractured rock is also an important, and often overlooked, source of recharge to karst aquifers (Hauwert, 2009). In fact, in a karst area in New Zealand more infiltration occurred through the soils and macropores than through large sinkhole drains (Gunn 1983). Note herein the term diffuse does not imply that water is flowing through the microscopic pore spaces within the limestone matrix, but refers to other processes including soil drainage, pool storage in open conduits and possibly urban leakage that may cause physical and chemical responses in drips that appear similar to flow through the matrix (Hauwert 2011). To avoid confusion, we use the term "slow flow "to describe this process hereafter.

Soils are often highly heterogeneous, which makes it difficult to characterize their hydraulic properties. Grego et al. (2006) found that 102 test holes, spaced 10 by $20 \mathrm{~m}$ across a 3.4 hectare field was insufficient to characterize soil moisture. Other studies have found high variability in recharge over small areas (De Silva, 2004) and variability with topography (Li et al., 2008). This evidence suggests that the portion of recharge to karst aquifers through the soil zone is an important and often poorly quantified source of recharge to karst aquifers.

The ability of water to infiltrate a soil is dependent on several factors including the conductivity of the soil and underlying rock, thickness and structures, initial water 
content from previous storms and time since onset of the precipitation event (Hillel, 1998). Where soil layers are continuous, the low permeability layers limit infiltration rate, but when soils contain structures such as root holes and macropores, water may preferentially flow through the structures at a rate much faster than would be expected based on the permeability of its limiting layer. Soil tracer tests have revealed that flow through soils is often faster than expected (Quisenberry and Phillips, 1976; Jarvis et al., 1987; Dekker and Ritsema, 1994; Flury et al., 1994; Kelly and Pomes, 1998). Furthermore, the National Research Council (2001) states that, "There exists a body of field evidence indicating that infiltration through fractured rocks and structured soils does not always occur as a wetting front advancing at a uniform rate."

In the BSS there have been conflicting estimations of upland recharge. During a study from July 1979 to December 1982 it was estimated that $85 \%$ of rainfall left as evapotranspiration, 9\% left as surface runoff, $5 \%$ recharged through major creeks and $0.9 \%$ recharge occurred in the intervening areas between the major creek channels (Slade et al., 1986). The estimated upland recharge value is significantly smaller than values measured in other karst areas around the world, in the adjacent Trinity Aquifer, and by (Hauwert, 2009). Hauwert (2009) points out potential sources of error in these estimates including lack of continuous discharge measurements upstream and downstream of the recharge zone, no direct evapotranspiration measurements, estimation of runoff coefficients (rather than direct measurement) for the intervening outcrop area between the creek channels, and an incorrect assumption of the size of the recharge area draining to Barton Springs.

A multiple year water balance performed at two upland sinkholes in the BSS indicated that the percentage of recharge occurring in the uplands is significantly higher than originally estimated (Hauwert, 2009). Another key finding of the study was that $26-34 \%$ of the rainfall infiltrated though the soil at one of the study sites. This is significant as upland soils in the BSS are often considered to somewhat impermeable and significant barriers to groundwater recharge.

\section{Study area}

The study area is located in the Recharge Zone of the BSS and is underlain by the Edwards group that is comprised of extensively karstified Cretaceous limestone and dolomite units in which many sinkholes and caves have formed. Four caves were monitored during two separate studies: Barker Ranch Cave in 2007 and three caves located near Deer Lane in south Austin (Blowing Sink Cave, Goat Cave and Maple Run Cave) from 2010 - present (Figure 1). The caves occur within the Leached and Collapsed, Regional Dense, Grainstone, Kirschberg, and Dolomitic members of the Edwards group. The Leached and Collapsed, Kirschberg and Dolomitic Members are highly karstified, hydraulically connected units that contain many of the known caves and recharge features in the area. The Regional Dense and Grainstone members are much less permeable, more resistant to weathering and water perches and flows laterally across the top of these beds until a breach is encountered (Hauwert 2009).

The caves selected for this study are located on City of Austin Water Quality Protection Lands. Because we focus on upland recharge through soils, Blowing Sink Cave will not be discussed further as several nearby sinkholes recharge it. The subsurface infiltration catchment area of Goat Cave (GC), Maple Run Cave (MR) and Barker

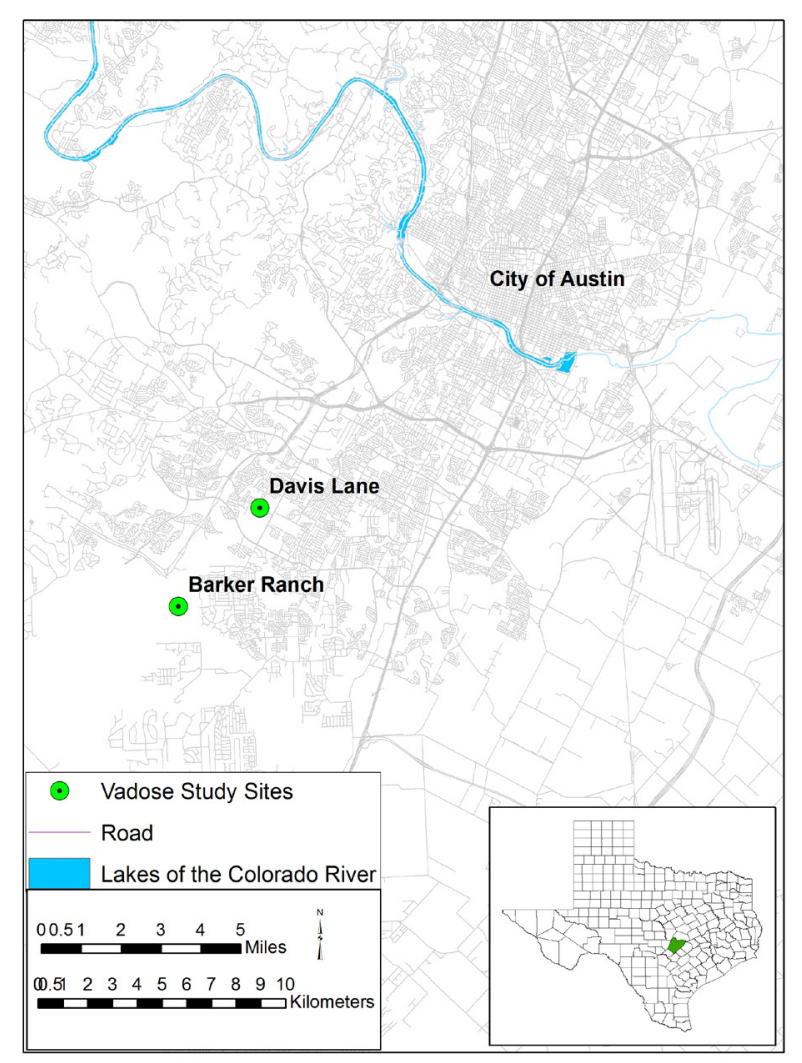

Figure 1. Overview of study area. 
Ranch Cave (BR) have been delineated (Hauwert and Cowan, 2013) and no discrete recharge features, such as sink holes or open apertures in the bedrock, are known to exist within their catchment areas. The majority of the delineated catchment areas are overlain by soils, and at Goat Cave and Maple Run Cave, by some impervious cover (roads and houses).

\section{Methods}

Chemical and dye tracer arrivals times and the natural geochemical response of several drips were monitored in the caves during two studies. A total of nine traces were completed at $\mathrm{BR}$ and three at GC and MR. Chemical tracers ( $\mathrm{KBr}, \mathrm{NH}_{4} \mathrm{CO}_{3}$, and an aqueous $\mathrm{Fe}$ solution), fluorescent dyes (Pyranine and Direct Yellow 96), and an optical brightener (Tinopal) were also used to determine recharge source areas and travel times to cave drips. Tracers were applied to soils overlying the caves and flushed through the soils into the vadose zone by natural rain events (Table 1, Figure 2, Figure 3). Fluorescent dyes in cave drips were detected using activated carbon receptors and optical brighteners were detected using unbleached organic cotton receptors. Chemical tracers were sampled using automatic samplers set at intervals ranging from 4 to 6 hours. Surface runoff samples were collected for comparison to cave drips to help determine drip sources and travel times. Analyses of fluorescent dyes and optical brighteners were performed at the Ozark Underground Laboratory in Protem, Missouri and chemical analyses were performed at the Lower Colorado River Authority Environmental Laboratory Services facility in Austin, Texas.

Driprate was measured continuously at three drip sites BR-Main, MR-Fissure and GC-Main. Driprate was not measured continuously at MR-Waterfall as the discharge at that site greatly exceeds the capacity of the tipping buckets during rain events. To collect enough drip water

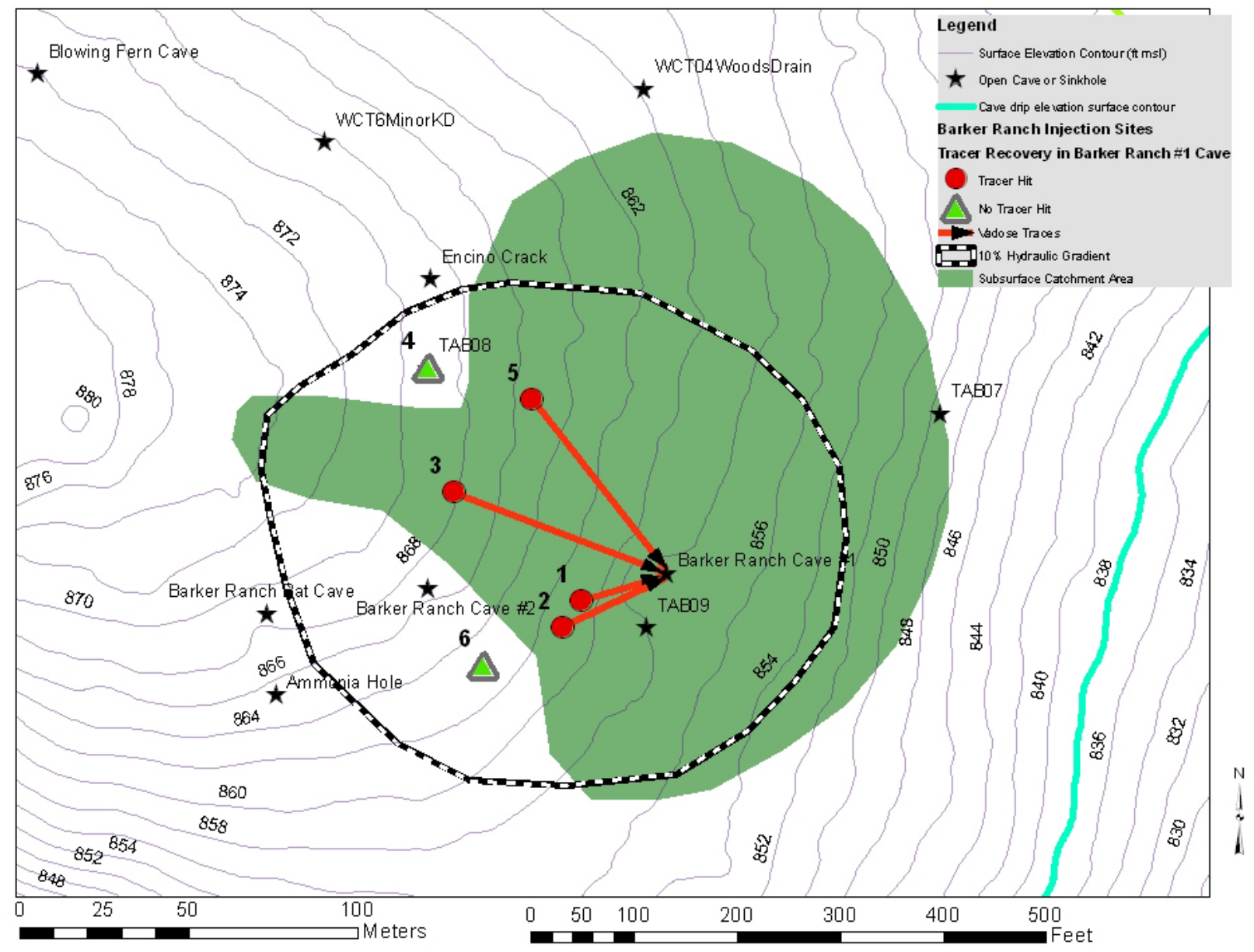

Figure 2. Summary of tracer injections at $B R$. 


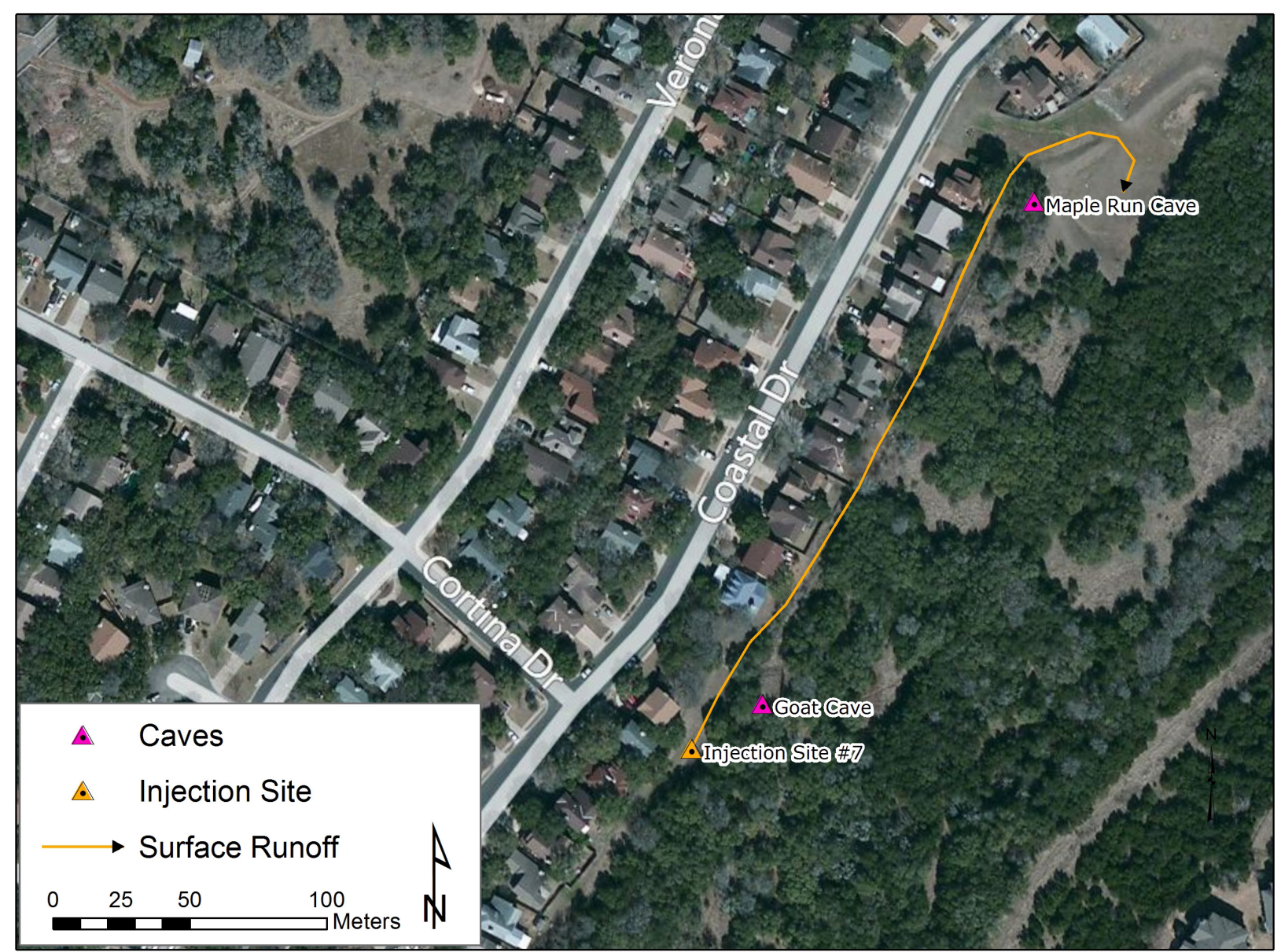

Figure 3. Summary of tracer injections at GC and MR.

Table 1. Tracer injection and detection summary. Injection locations correspond to locations shown on Figure 2 and Figure 3.

\begin{tabular}{|c|c|c|c|c|}
\hline Date Injected & $\begin{array}{l}\text { Injection } \\
\text { Location }\end{array}$ & Tracer Injected & Detection & Arrival Time \\
\hline $3 / 13 / 2007$ & 1 & $\mathrm{KBr}$ & BR-Main & 4-7 hours \\
\hline $3 / 14 / 2007$ & 2 & $\mathrm{NaCl}$ & Inconclusive & \\
\hline $3 / 14 / 2007$ & 3 & $\mathrm{~N}_{\mathrm{H} 4 \mathrm{C}} \mathrm{O} 3$ & BR-Main & $\sim 48$ hours \\
\hline $5 / 27 / 2007$ & 4 & Pyranine and $\mathrm{KBr}$ & None & \\
\hline $5 / 27 / 2007$ & 5 & $\mathrm{NH}_{4} \mathrm{CO}_{3}$ and $\mathrm{KI}$ & Br-Main $\mathrm{NH}_{4} \mathrm{CO}_{3}$ & $<26$ hours \\
\hline $5 / 27 / 2007$ & 6 & $\mathrm{NaCl}$ & Inconclusive & \\
\hline $9 / 3 / 2007$ & 2 & Direct Yellow 96 and Fe & BR-Main Fe & 2 hours \\
\hline $9 / 3 / 2007$ & 6 & $\mathrm{NH}_{4} \mathrm{CO}_{3}$ & None & \\
\hline $9 / 3 / 2007$ & 3 & Pyranine and $\mathrm{KBr}$ & Inconclusive & \\
\hline $1 / 25 / 2012$ & 7 & Tinopal and $\mathrm{Fe}$ & GC-Entrance & 12 days $*$ \\
\hline $1 / 8 / 2013$ & 8 & Pyranine and $\mathrm{KBr}$ & None & \\
\hline $1 / 8 / 2013$ & 7 & Tinopal and Fe & $\begin{array}{c}\text { GC-Entrance and MR- } \\
\text { Waterfall }\end{array}$ & $<8$ days* \\
\hline
\end{tabular}

*Dye detected on passive cotton sampler deployed for 1 or more weeks. In process of analyzing water samples taken at more frequent intervals to determine arrival time. 
for chemical analyses, small clusters of active drips were monitored at each of the sites. Plastic tarps were used to direct drip water into a collection apparatus consisting of a funnel connected to a sonde flow through cell (physiochemical parameters), that discharged into a tipping bucket gauge (flow rate) followed by a plastic sampling container from which automatic samplers could collect water samples. At MR-Waterfall, a small tarp was used to direct flow into a five-gallon bucket so that an automatic sampler could collect samples and a sonde could record physiochemical parameters. All components coming into contact with drip water were cleaned in a three-step process using distilled water, laboratory soap, and deionized water. Some gaps in drip rate data exist due to logger failures.

Hydrograph and chemograph separation and tracer arrival times were used to determine when breakthrough of recharging water occurred at various drip sites. Chemograph separation was conducted using changes in $\mathrm{Mg} / \mathrm{Ca}$ and $\mathrm{Sr} / \mathrm{Ca}$ in dripwater. These ratios fluctuate based on the extent of water-rock interaction, which is controlled by flow rate (Musgrove and Banner, 2004). As residence time increases, progressive water-rock interaction increases the $\mathrm{Mg} / \mathrm{Ca}$ and $\mathrm{Sr} / \mathrm{Ca}$ ratios due to incongruent dissolution of dolomite and precipitation of calcite (Figure 4, Musgrove and Banner, 2004). In the vadose zone, residence time is controlled by flowpath, which can be conceptualized as being either conduit flow, meaning short residence time with little chance for water-rock interaction, or slow flow, which is characterized by long residence time with more extensive water-rock interaction.

\section{Results}

\section{Tracer Arrival}

Several tracer breakthroughs were detected whereas some tracers were never detected (Table 1). At $\mathrm{BR}$, tracers typically arrived at the monitoring sites within a few hours of application to the soils (Figure 5). Tinopal has been detected at MR-Waterfall and GC-Entrance by cotton receptors within days of injection. Water samples are taken at more frequent intervals (typically daily during tracing) than the cotton receptors are changed (typically weekly during tracing). Water samples that were collected during the interval that cotton receptors testing positive for Tinopal were deployed will be analyzed to further constrain tracer arrival times.

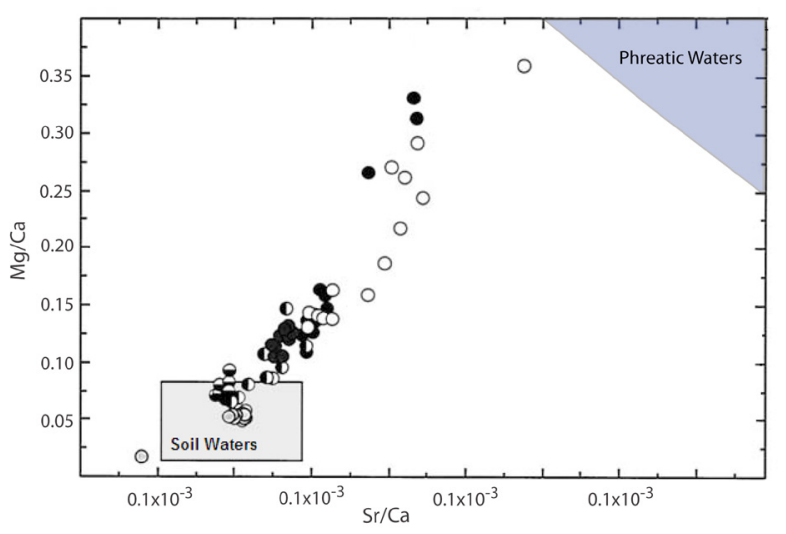

Figure 4. Geochemical changes caused by increased residence time as measured in vadose and phreatic waters of the Edwards Aquifer. From Musgrove and Banner 2004.

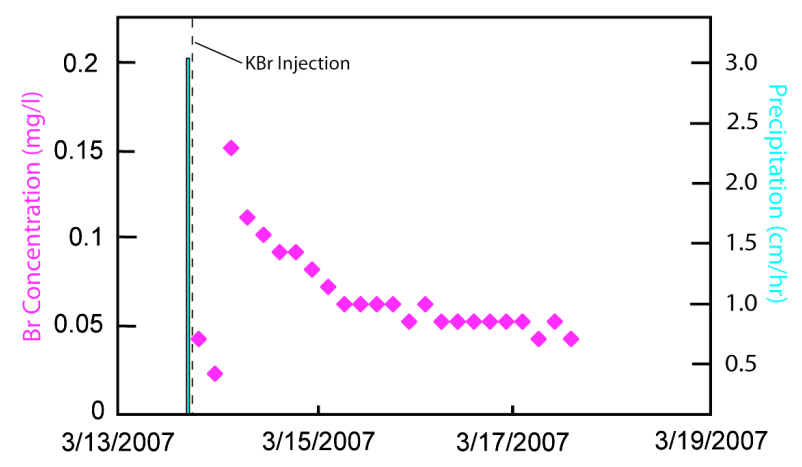

Figure 5. Breakthrough of Bromide tracer measured at BR-Main within a few hours of application to the soil.

\section{Driprate Response}

Driprate responded rapidly (within a few hours of the onset of rainfall events) at the MR-Main and GC-Main drip sites (Figure 6). MR-Fissure had a delayed drip response to storm events (Figure 6) indicating that that drip has a more slow flow source than other monitored drips. An automatic sampler collected samples at one site in MR where driprate was not monitored (MR-Waterfall) due to the very large volume of discharging at that site. Based on our observations, MR Waterfall appears to be connected to a water quality pond located approximately 10 meters away as responds within a couple hours of water entering the pond. There are no discrete recharge features (i.e. sinkholes) within the source area delineated for MR and GC but there are some features within source area of BR; however, tracers applied to the soils in the BR source area were recovered at BR-Main. 

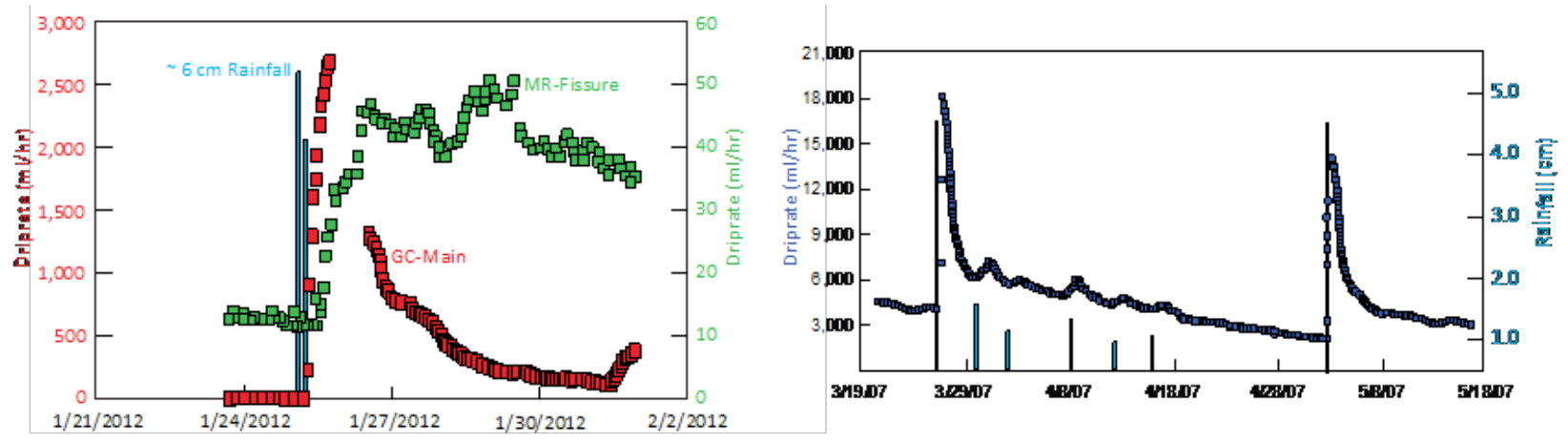

Figure 6. Representative driprate responses to rainfall events at MR-Fissure, GC-Main and BR-Main.

\section{Geochemical Response}

A response in the trace element rations $(\mathrm{Mg} / \mathrm{Ca}$ and $\mathrm{Sr} /$ Ca) to storm events was observed at all sites monitored. This response was more pronounced at Barker Ranch than at Goat Cave (Figure 7). A decrease in the ratios was observed several hours after the onset of the rain events and subsequent increase in driprate. The decrease in trace element ration is interpreted shorter residence time water (related to the rain event) reaching the monitoring sites.

\section{Discussion}

The lack of discrete recharge features within the mapped source area of MR and GC indicates that recharge to the caves is likely occurring through the soil and epikarst and not through discrete features such as sinkholes or solution cavities. The rapid drip rate response observed at BR-Main, GC-Main and MR-Waterfall suggests that recharge through the soils and epikarst is quite efficient. Examining driprate response alone is not sufficient to prove that rapid soil infiltration and transmission through the epikarst is occurring. It is well documented that pressure waves can rapidly propagate through the vadose zone and cause a rapid increase in driprate that is not associated with the arrival of recently recharged groundwater. To gain a better understanding of how rapidly recharge is occurring one must examine driprate response in conjunction with geochemical response and tracer arrival times.

With a variable flow rate that is highly responsive to precipitation events, BR is characteristic of a system dominated by conduit flow. Driprate increases of several thousand $\mathrm{ml} / \mathrm{hr}$ have been observed over a period of hours (Figure 6). Anecdotal evidence suggests that there is some component of slow flow at Barker Ranch drip as the site has continued to drip, albeit slowly, through a recent two year drought period. Also recorded driprate data shows that a baseflow component is present at the site. Dripwater $\mathrm{Mg} / \mathrm{Ca}$ and $\mathrm{Sr} / \mathrm{Ca}$ values at Barker Ranch respond significantly to storms (Figure 7). For example, over a five-day period $\mathrm{Mg}$ / $\mathrm{Ca}$ and $\mathrm{Sr} / \mathrm{Ca}$ are strongly correlated with drip rate response to a single day storm. Prior to, and during the initial few hours of the storm event, $\mathrm{Mg} / \mathrm{Ca}$ and $\mathrm{Sr} / \mathrm{Ca}$ ratios remain relatively high, suggesting that the dripwater emerging at that time had experienced greater water-rock interaction. Samples taken two days after the event had the lowest $\mathrm{Mg} / \mathrm{Ca}$ and $\mathrm{Sr} / \mathrm{Ca}$ values, whereas samples taken 4 days after the storm event had increased to near pre-storm values (Figure 7). This is consistent with the water-rock interaction model in that waters sampled previous to and during the early part of the storm event underwent more extensive water-rock interaction and likely represent the flushing of "older" vadose waters by the rapid infiltration of storm water. Four days after the storm event $\mathrm{Mg} / \mathrm{Ca}$ and $\mathrm{Sr} / \mathrm{Ca}$ returned to pre-storm values.

These temporal variations suggest that Barker Ranch dripwater is sourced by a small slow flow component overprinted by conduit flow during storm events. Similar but somewhat muted geochemical responses were observed at GC-Main (Figure 7). Chemical tracers that were applied to the soil near BR were detected multiple times BR-Main and these chemical tracer arrivals typically occurred concurrently with decreases in trace element ratios. Tinopal detections occurred at MR-Waterfall and GC-Main but the arrival time of those tracers will require further analyses to better constrain arrival times (Table 1).

Optical brighteners and dyes applied simultaneously with chemical tracers were never detected in BR, even 

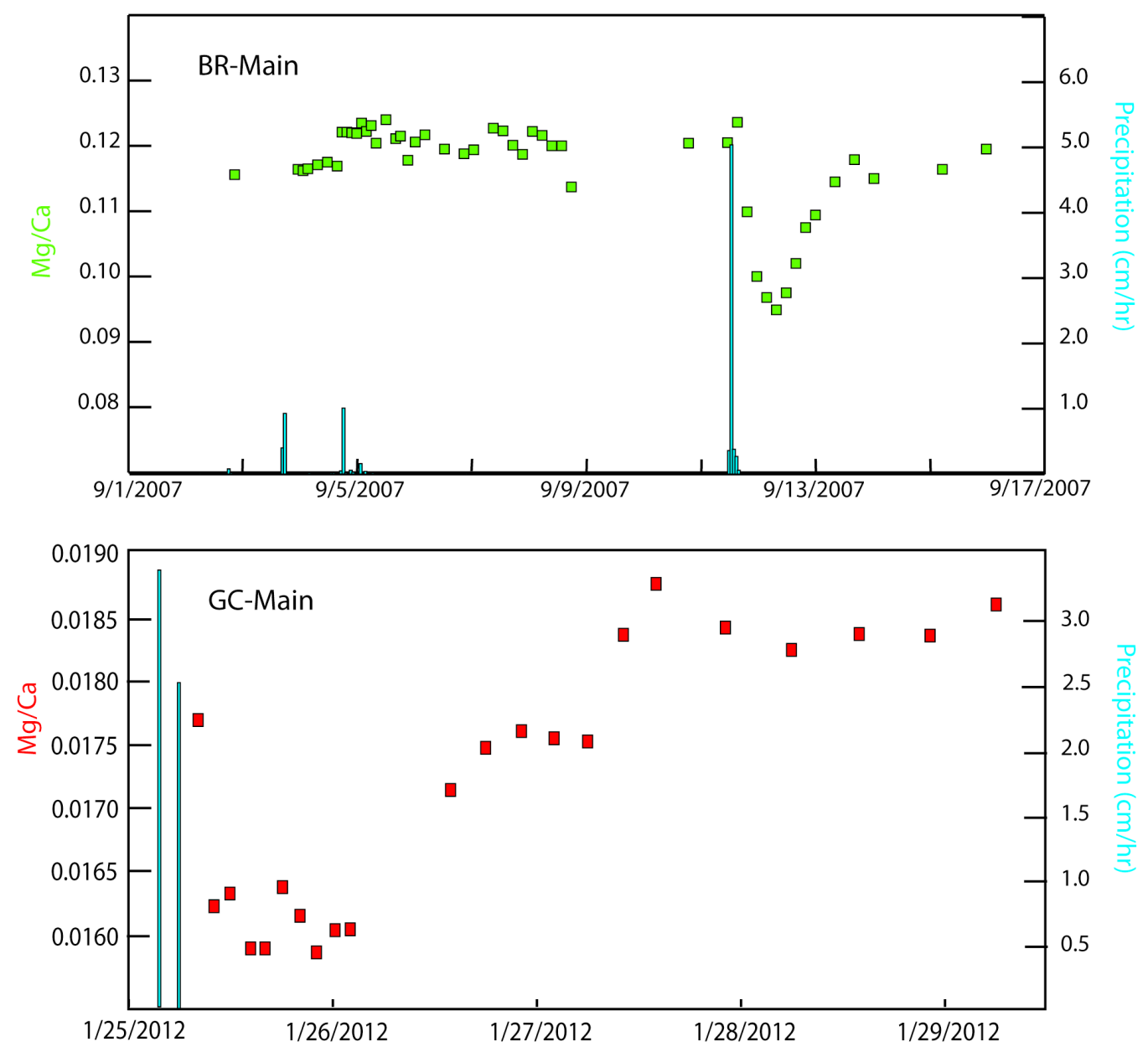

Figure 7. Geochemical response to rainfall events at BR-Main and GC-Main.

when chemical tracers were. The optical brighteners and dyes have a high affinity for clay particles and were likely adsorbed by the clay rich soils overlying the study area. Optical brighteners that were applied to the soil near GC were detected at GC-Entrance and MR-Waterfall. Much of the Tinopal was likely adsorbed by clay particles in the soil similar to dyes applied to the soils near Barker Ranch; however, a greater mass or Tinopal was applied near GC than was previously applied at BR, resulting in some of the Tinopal penetrating through the soil zone and into GC. Some of the Tinopal applied near GC was washed down a drainage and into a retention pond that overlays MR (Tinopal could be seen in the water flowing into the retention pond). The pond is lined by thick, locally sourced soils, yet Tinopal was detected in MR-Waterfall, suggesting rapid infiltration through the soils.
The rapid driprate, geochemical response, and tracer arrival times indicate that water is rapidly recharging through the soil zone. Soils in the study area are clay rich and have low Ksat values ranging from 0.06$0.57 \mathrm{in} / \mathrm{hr}$ (USDA, 2012), suggesting that such rapid recharge is not possible. Because the soils are clay rich, they shrink and swell with continual wetting and drying. This shrinking and swelling can creates macropores, which are visible on the surface during dry periods (Figure 8).

When soils contain structures such as root holes and macropores, water may preferentially flow through the structures at a rate much faster than would be expected based on the permeability of its limiting layer. Soil tracer tests have revealed that flow through soils is often faster than expected (Quisenberry and Phillips, 1976; Jarvis et al., 1987; Dekker and Ritsema, 1994; Flury et al., 2994; 


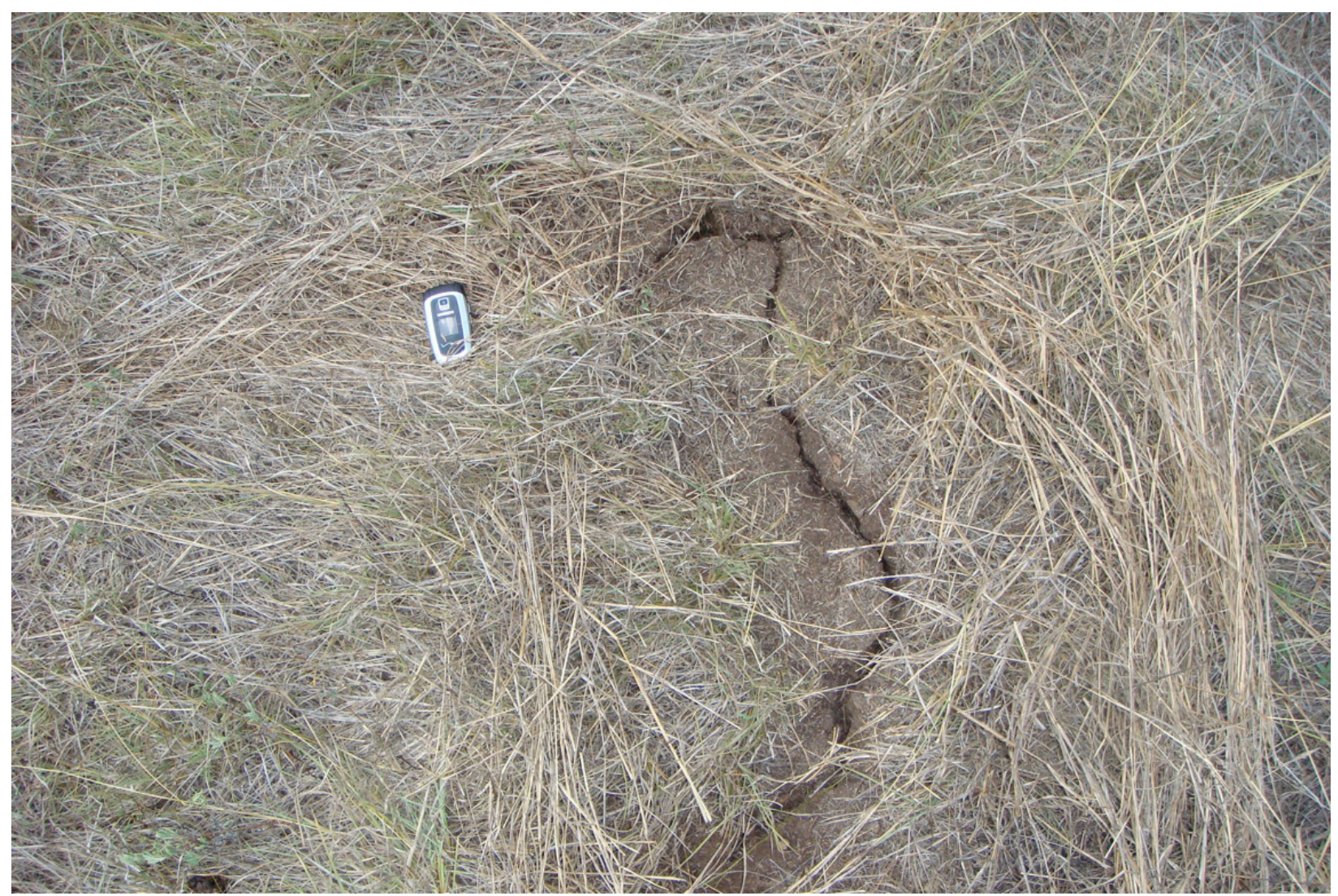

Figure 8. Macropore observed near Barker Ranch. Representative of macropores found throughout study area when soils are dry. The macropore was not enlarged but vegetation was removed to better photograph. Note cell phone is approximately two inches tall by one inch wide.

Kelly and Pomes, 1998). It is likely that macropore flow is responsible for the rapid recharge of storm water observed in the study area despite the lack of discrete recharge features within the mapped source areas of MR and GC. Our findings suggest that monitoring cave drips is an effective method for characterizing recharge through soils in karst settings.

\section{References}

De Silva, RP. 2004. Spatial variability of groundwater recharge - I. Is it really variable?:Journal of Spatial Hydrology 4 (1).

Dekker, LW, Ritsema, CJ. 1994. Variation in water content and wetting patterns in Dutch water repellent peaty clay and clayey peat soils: Catena 28 (1) 89-105.

Flury, M, Fluhler, H, Jury, WA, Leuenberger, J. 1994. Susceptibility of soils to preferential flow of water: A field study. Water Resource Resources 30 (1) 1945-1954.

Grego, CR, Vieira SR, Antonio, AM, Della Rosa SC. 2006. Geostatistical analysis for soil moisture content under the no tillage cropping system. Scientia Agricola 63 (4) 341-350.
Gunn, J. 1983. Point recharge of limestone aquifers-A model from New Zealand karst. Journal of Hydrology 61 (1) 19-29.

Hauwert, NM. 2009. Groundwater flow and recharge within the Barton Springs Segment of the Edwardsa Aquifer, Southern Travis and Notrhern Hays Counites, Texas [doctoral dissertation]. Austin (TX): University of Texas at Austin. 214p.

Hauwert, NM. 2011. Interconnection of the Trinity (Glen Rose) and Edwards Aquifers along the Balcones Fault Zone and Related Topics. Proceedings of the Karst Conservation Initiative; Austin, Texas.

Hauwert, NM, Cowan, BD. 2013. Delineating source areas to cave drips and cave streams in Austin Texas, USA. Proceedings of the Thirteenth Multidisciplinary Conference on Sinkholes and the Engineering and Environmental Impacts of Karst; Carlsbad, New Mexico.

Hillel, D. 1998. Environmental Soil Physics: San Diego (CA): Academic Press.

Jarvis, NJ, Leeds-Harrison PB, Dosser, JM. 1987. The use of tension infiltrometers to assess routes and rates of infiltration in a clay soil. European Journal of Soil Science 38 (4). 
Kelly, BP, Pomes, ML. 1998. Preferential flow and transport of nitrate and bromide in claypan soil. Groundwater 36 (3) 484-494.

Li, XY, Contreras, S, Solé-Benet, A. 2008. Unsaturated hydraulic conductivity in limestone dolines, Influence of vegetation and rock fragments. Geoderma 145 (1) 288-294.

Musgrove, M, Banner, JL. 2004. Controls on the spatial and temporal variability of vadose dripwater geochemistry: Edwards Aquifer, central Texas. Geochimica et Cosmochimica, 68 (5) 1007-1020.

National Research Council. 2001. Conceptual Models of Flow and Transport in the Fractured Vadose Zone. Washington (DC): National Academy Press.

Quisenberry, VL, Philips, R.E. 1976. Percolation of surface-applied water in the field. Soil Science Society of America Journal 40 (1) 484-489.

Slade, R, Dorsey, M, Stewart, S. 1986. Hydrology and water quality of the Edwards Aquifer associated with Barton Springs in the Austin Area, Texas. USGS Water-Resources Investigations Report 86-4036.

USDA Web Soil Survey [Internet]. 2013. USDA. gov [cited 2013 February 11]. Available from: http://websoilsurvey.nrcs.usda.gov/app/ WebSoilSurvey.aspx 
376 NCKRI SYMPOSIUM 2 13TH SINKHOLE CONFERENCE 